to place that hitherto empirical subject on a sounder scientific basis. Mr. Sopwith brings to his new task, not only research experience, but also a marked ability to appreciate and then simplify analytical methods so that they can be readily applied to practical problems of engineering design.

Economics at the University of Sheffield: Dr. G. P. Jones

DR. G. P. Jones, reader in economic history in the University of Sheffield, has been appointed professor of economics in the University, in succession to Prof. D. Knoop, who retires in September. Dr. Jones is no stranger to Sheffield or Sheffield people, for he has been a member of the University staff since 1926 when he was appointed lecturer in economic history, and in recognition of the distinction of his scholarship and research the University conferred upon him in 1946 the title of reader. He has been especially interested in the organisation of the building industry from medieval to early modern times, to which field he has made distinguished contributions. In addition, ever since he has been in Sheffield, Dr. Jones has been closely connected with adult education, and throughout the whole period April 1940July 1946 he did great service to the cause of education in H.M. Forces as secretary to the Sheffield Regional Committee, under the auspices of which more than twelve thousand lectures and classes were held for members of the Army, the R.A.F. and Women's Auxiliary Forces.

\section{Royal Geographical Society: Awards for 1948}

H.M. THE KING has approved the award of the Royal Medals for 1948 of the Royal Geographical Society as follow : Founder's Medal, to Mr. Wilfred Thesiger, for his contributions to the geography of southern Arabia and for his recent crossings of the Southern Arabian desert, the Rub al Khali ; Patron's Medal, to Mr. Thomas H. Manning, of the Geodetic Survey of Canada, for his explorations and survey work in the Canadian Arctic, including the mapping of Southampton Island and the Foxe Basin shores of Baffin Island, and for his successful adaptation of Eskimo methods of travel. The Council of the Society has made the following awards : Victoria Medal, to Prof. Frank Debenham, professor of geography in the University of Cambridge, for his work in geographical education and for his contributions to polar geography and exploration in the Antarctic and as first director of the Scott Polar Research Institute at Cambridge. Murchison Grant, to Mr. Robert W. Steel, lecturer in Colonial geography at the University of Oxford, for geographical work on the West African Ashanti Social Survey, 1945-46. Back Grant, to Mr. Alan J. Marshall, for exploratory and scientific work as leader of the Oxford University Exploration Club Expedition to Jan Mayen Island, 1947. Cuthbert Peek Grant, to Dr. Donald F. Thomson, for his explorations and anthropological studies in Arnhem Land, Northern Territory, Australia. Gill Memorial, to Mr. William W. Williams, lecturer in geography at the University of Cambridge, for original research during the War on the determination of underwater beach gradients.

\section{Royal Asiatic Society of Bengal: Medal Awards}

THE following medal awards of the Royal Asiatic Society of Bengal were announced at the annual meeting held on February 16: Barclay Memorial Medal, a biennial award for contributions to medical or biological science with reference to India, to Rai Bahadur K. C. Mehta, principal of Agra College, for his contributions to the study of "Cereal Rusts in India" ; Joy Gobind Law Memorial Medal, a tri. ennial award for contributions to the study of zoology in Asia, to Dr. Lieven Ferdinand de Beaufort, pro. fessor of zoology in the University of Amsterdam and director of the Zoological Museum at Amsterdam, for his contributions to the study of "Fishes of the Indo-Australian Archipelago" ; Paul Johannes Bruhl Memorial Medal, a triennial award for contributions to the study of Asiatic botany, to Prof. S. R. Bose, professor of botany, Carmichael Medical College, Calcutta, for his original research on polyporin from fungi ; Dr. Bimala Churn Law Gold Medal, an annual award for contributions to Indological studies, to Dr. B. M. Barua, professor of Pali in the University of Calcutta, for his contributions to the study of Buddhism in India; Sir Jadunath Sarkar Gold Medal, a newly instituted biennial award for contributions to Indological researches from the thirteenth century A.D. up to A.D. 1802, to Sir Panduranga S. S. Pissurlencar, for his contributions to the study of the history of the Marathas and the Deccani Muslim Powers down to the time of Tipu Sultan.

Council for 1948

THe members of Council of the Society for 1948 are as follows: President, Dr. W. D. West; Vice. Presidents, Dr. B. C. Law, Maharajadhiraja Bahadur Sir U. C. Mahtab, Dr. M. N. Saha, Sir B. L. Mitter ; General Secretary, Dr. K. N. Bagchi; Treasurer, K. P. Khaitan; Philological Secretary, Dr. S. K. Chatterji; Joint Philological Secretary, Dr. M. Ishaque; Natural History Secretaries, Dr. K. Biswas (biology) and Dr. S. K. Mitra (physical sciences); Anthropological Secretary, Dr. Verrier Elwin; Historical and Archaeological Secretary, H. Waddington; Medical Secretary, Lieut.-Colonel C. L. Pasricha; Library Secretary, Dr. B. S. Guha; Other Members of Council, C. C. Blagden, H. F. Bensly, Dr. A. H. M. Mohiyuddin, Sir A. H. Ghuznavi and Ramaprasad Mookerjee.

The following were elected fellows of the Society : Rao Bahadur K. V. Rangaswami Aiyangar, director of public instruction, Travancore; Dr. B. M. Barua, professor of Pali, University of Calcutta; Dr. F. G. Percival, of the Tata Iron and Steel Co. Prof. D. R. Bhandarkar, formerly of the University of Calcutta, was elected an honorary fellow.

\section{Corrosion Research in Canada}

THE National Research Council, Canada, has established a committee to assemble information on all aspects of corrosion and promote its dissemination. In the first instance, a survey is being made of existing Canadian facilities for the study of corrosion and means of combating its effects. It is proposed to assist Canadian universities in making studies of the fundamental chemical and electrochemical reactions that cause deterioration of metals in service, and in the training of students in the techniques of corrosion research and prevention. In the development of a programme of research in this field the committee is seeking the co-operation of all organisations and industries that are concerned in dealing with corrosion problems, and to obtain information a questionnaire has been prepared and given wide distribution.

The chairman of the new committee is Dr. R. R. Rogers, Department of Mines and Resources, and the secretary is D. Wolochow, Division of Building 
Research, National Research Council, Ottawa. Other members of the Committee are: H. J. Butterill (Intermational Nickel Co.), N. Cohen (National Research Council), R. Judge (Department of National Defence, representing the Defence Research Board), Frank D. Forward (University of British Columbia), H. P. Godard (Aluminium Laboratories, Ltd.), Lorne Sproule (Imperial Oil Ltd.), Dr. C. Y. Hopkins (National Research Council), E. T. Hurley (Canadian National Railways), H. D. Smith (Nova Scotia Research Foundation), and Frank Twining (Canadian Industries, Ltd.).

\section{'Supermalloy' : a New Magnetic Alloy}

InoN-nickel alloys, containing 35-90 per cent nickel, have permeabilities very much greater than that of iron. These alloys, called 'permalloys', are especially useful commercially for transformers. The addition of one or more of the elements molybdenum, chromium and copper to permalloys has proved advantageous. 'Mumetal', which contains usually 5 per cent copper, 2 per cent chromium, 75 per cent nickel and 18 per cent iron, is perhaps the best known of the permalloys. It is used in transformers suitable for high frequencies and is notable not only for its high initial permeability (between 10,000 and 30,000 ) and its high electrical resistivity $(60 \mathrm{microhm}$. $\mathrm{cm}$.) but also for the very simple heat treatment required in its preparation. O. L. Boothby and R. M. Bozorth have described recent developments in these highnickel alloys for use at low inductions ( $J$. A ppl. Phys., 18, 173 ; 1947 ; see also Bozorth, R. M., Rev. Mod. Phys., 19, 38; 1947). The now material 'Supermalloy' (su-perm'-al-loy), developed during the Second World War and already supplied in considerable quantities to the U.S. Navy, contains 5 per cent molybdenum and 79 per cent nickel, the remainder being mainly iron with a little manganese. The alloy is heat-treated, being maintained at $1,300^{\circ} \mathrm{C}$. in pure dry hydrogen and then cooled from $600^{\circ} \mathrm{C}$. to $300^{\circ} \mathrm{C}$. at a critical rate. Whereas its electrical resistivity is about the same as for 'Mumetal', its initial and maximum permeabilities are many times larger, 50,000-150,000 for the initial, and 600,000$1,200,000$ for the maximum, permeabilities. 'Supermalloy' can be produced in the form of very thin insulated tape, suitable for transformer cores, and it is claimed that the use of this new alloy in communication transformers permits a threefold increase in the range of frequencies transmitted, and a pulse duration three times that previously obtained.

\section{Colchicine, its Chemical and Biological Properties}

THE sessional inaugural lecture to the Chemical Society of University College, Dublin, was delivered on February 3 by Prof. J. W. Cook, regius professor of chemistry, University of Glasgow, who spoke on colchicine. Colchicum, a drug of great antiquity, is extracted from meadow saffron (Colchicum autumnale). It is present in all parts of the plant, especially in the seeds, which contain up to 0.75 per cent of the active principle. The poisonous nature of colchicum was known to Dioscorides; its toxic symptoms and its only therapeutic use, in the treatment of gout, are described in "The Herball", by John Gerarde, published in 1597. Colchicine, the active principle of colchicum, was isolated by Pelletier in 1820 , but was not obtained pure and crystalline until 1915. Its composition and its functional groups were investig. ated by Zeisel, and the main features of its molecular structure were established by Windaus in 1924.
Colchicine, $\mathrm{C}_{22} \mathrm{H}_{25} \mathrm{O}_{6} \mathrm{~N}$, contains three rings, one of them a trimethoxylated benzene ring, an acetylamino group, and an inert carbonyl group, and it is the methyl ether of an enol. Recent studies have shown that revision of the Windaus structure is necessary, and the molecular formula of a degradation product, deaminocolchinol methyl ether, has been established beyond doubt by Barton, Cook and Loudon (1945). The final details of structure of colchicine itself still require to be settled. The molecule probably contains at least one seven-membered carbon ring. The remarkable effect of colchicine in arresting mitosis in nuclei at the metaphase was discovered by Lits, a pupil of Dustin; it is effective in a dilution of 1 in $10^{8}$, and has important biological applications. Thus, it may be used as an index of the rate of growth of tissues, and of the activity of various classes of growth-stimulating hormones. An effect on plants, first studied by Havas, was shown by extensive investigations of Blakeslee to result in the production of polyploidy, leading to new and improved varieties of flowers, fruits and cereals.

\section{Insect Pests of Flour}

UNDER the title of "Insect Pests of Food: The Control of Insects in Flour Mills" (London : H.M. Stationery Office. 7s. 6d. net), the Ministry of Food has recently issued a useful 84-page practical bulletin by J. A. Freeman and E. E. Turtle. The authors are, respectively, chief entomologist and chief chemist of the Infestation Control Division of the Ministry. The bulletin deals with those insects and mites that affect the flour miller: it describes the measures that can be adopted in order to prevent infestation and how to control such insects should they manage to establish themselves. It is divided into three main sections, namely, methods of prevention and control; life-histories of insects and mites; and infestation in the mill. The losses which these creatures inflict on the industry may be assessed as damage to wheat; interference with productive processes; contamination and spoiling of finished products and loss of goodwill and trade.reputation. The methods of control that are described are only those which have been examined by the Ministry and thoroughly proved in practice. It should not be inferred, however, that these methods are in any sense static. New work is continually going on, and, as examples, may be mentioned that which is being done in assessing the value of D.D.T. and of benzene hexachloride ('Gammexane') in this connexion. The bulletin is very well illustrated by numerous halftone plates and text-figures.

\section{The Bird Watcher}

THE company of bird watchers grows larger with succeeding years, its ranks including a diversity of enthusiasts, from the scientific ornithologist to the schoolboy and schoolgirl recruit. It is to help these latter that the Daily Mail has issued a number of booklets on Nature subjects and so on, the latest of its School Aid series being "Bird Watching" by Mr. Stuart Smith $(2 s$.$) . This consists of some thirty-four$ pages of excellent advice on how to study birds, with a number of admirable photographs by $\mathrm{Mr}$. Eric Hosking, supplemented by equally admirable drawings by Mr. Edward Bradbury and eight colour pictures, the latter being reproductions of plates from Gould's "Birds of Great Britain". It is wonderful how fresh in spirit and treatment the Gould bird portraits remain, while for accuracy of feather detail 